Status Report 2016-2019

\title{
The Western Continental Margin of India: Indian Scientific Contributions (2016-2018)
}

\author{
DHANANJAI K PANDEY*, NISHA NAIR and AJEET KUMAR \\ ESSO-National Centre for Polar and Ocean Research, Vasco da Gama, Goa, India
}

(Received on 10 August 2019; Accepted on 29 September 2019)

\begin{abstract}
The western continental margin of India (WCMI) is among some of the most spectacular passive margins with numerous pronounced morpho-tectonic features. While it preserves early imprints of the final Gondwana dispersal, deep post-rift sedimentary archives on this margin are crucial for deciphering the India-Eurasia collisional tectonics and its long term climatic response. With a varying degree of magmatism along its $\sim 2500 \mathrm{~km}$ long N-S stretch, the WCMI has a gently dipping wide shelf in the north as compared to the steep and narrower shelf in the south. Due to its vital link in understanding the formation and evolution of passive continental margins, the past few years have witnessed significant growth in the geoscientific studies especially led by the Indian geoscientific community. Here we collate some of the recent Indian contributions (2015-2018) aimed at augmenting our knowledge about the origin and subsequent evolution of this complex passive margin. Scientific contributions discussed in this review primarily focuses on various tectonic fragments/ domains along WCMI namely-submarine fan, shelf, seamounts, aseismic ridges, and abyssal basins. These recent studies using new seismic, bathymetric, potential field and magnetic data have targeted both aspects of the WCMI fairly well in terms of unraveling its early as well as late structural and tectonic evolution. We also make a particular mention of the firstever deep-sea drilling through the International Ocean Discovery Program (IODP) expedition 355 in the eastern Arabian Sea and the initial scientific findings emanating from it.
\end{abstract}

Keywords: Western Indian Margin; Laxmi Ridge; Laxmi Basin; Laccadive Ridge; Laccadive Basin; Arabian Basin; Indus Fan

\section{Major Structural Elements Along The Western Continental Margin of India}

The Western Continental Margin of India (WCMI) is a passive continental margin having undergone repeated drift-drift transitions since the mid-late Cretaceous ( 120-65 Ma). The WCMI is presently a seismically quiescent margin that inherits crucial records of the continental break-up of India from Madagascar and the Seychelles blocks and subsequent opening of the northwestern Indian Ocean. The WCMI is characterized by $\sim 300 \mathrm{~km}$ wide continental shelf in the north (offshore Gujarat) that gradually narrows down to $\sim 50 \mathrm{~km}$ in the south (offshore Kerala) (Fig. 1). Prominent structural features along the western continental margin include the NW-SE trending Laxmi Ridge (LR), Laxmi Basin (LB), Chagos-Laccadive Ridge, and adjoining basins, Prathap Ridge complex and numerous associated seamount chains (e.g. Panikarridge). Towards further north, adjoining India-Pakistan shelf lies an extensive submarine Indus Fan system. This offshore depositional system is one of the largest sediment repositories sourced through weathering, erosion and mass wasting mechanisms ever since the onset of India-Eurasia collision ( $\sim 50 \mathrm{Ma})$. Much of the offshore sedimentation in the eastern Arabian Sea adjoining WCMI is attributed to the drainage systems emanating from the western Himalaya and the central Indian peninsular discharge. Extensive geological and geophysical studies have been carried out over several decades, which have rendered significant understanding about the structural style and long term sedimentation patterns along this margin. Thick sedimentation in the shelf regions is also envisaged hydrocarbon worthy. Precise knowledge about these geological processes is crucial for evaluating longterm links between mountain-building processes and

*Author for Correspondence: E-mail:pandey@ncpor.res.in 
paleo-climatic events, resource potential as well as natural disasters. The global relevance of this passive margin can be inferred from the fact that an International Ocean Discovery Program (IODP) led expedition carried out coring and drilling operations in 2015 to sample the Cenozoic sedimentary column as well as the igneous basement at two sites in the Laxmi Basin (Sites U1456 and U1457) for the first time. During the last four years (2015-2018), substantial progress has been made towards improving our knowledge about the morpho-tectonics and sedimentation history along WCMI in the Arabian Sea. In what follows next, we present an overview of some of the key findings by the leading geoscientific investigations, particularly by the Indian scientists.

\section{Tectonics of Major Structural Elements Along the Northwestern Continental Margin of India}

\section{Deep-sea Scientific Drilling in the Laxmi Basin}

An IODP drilling in the eastern Arabian Sea in 2015 marked a significant development in terms of collecting

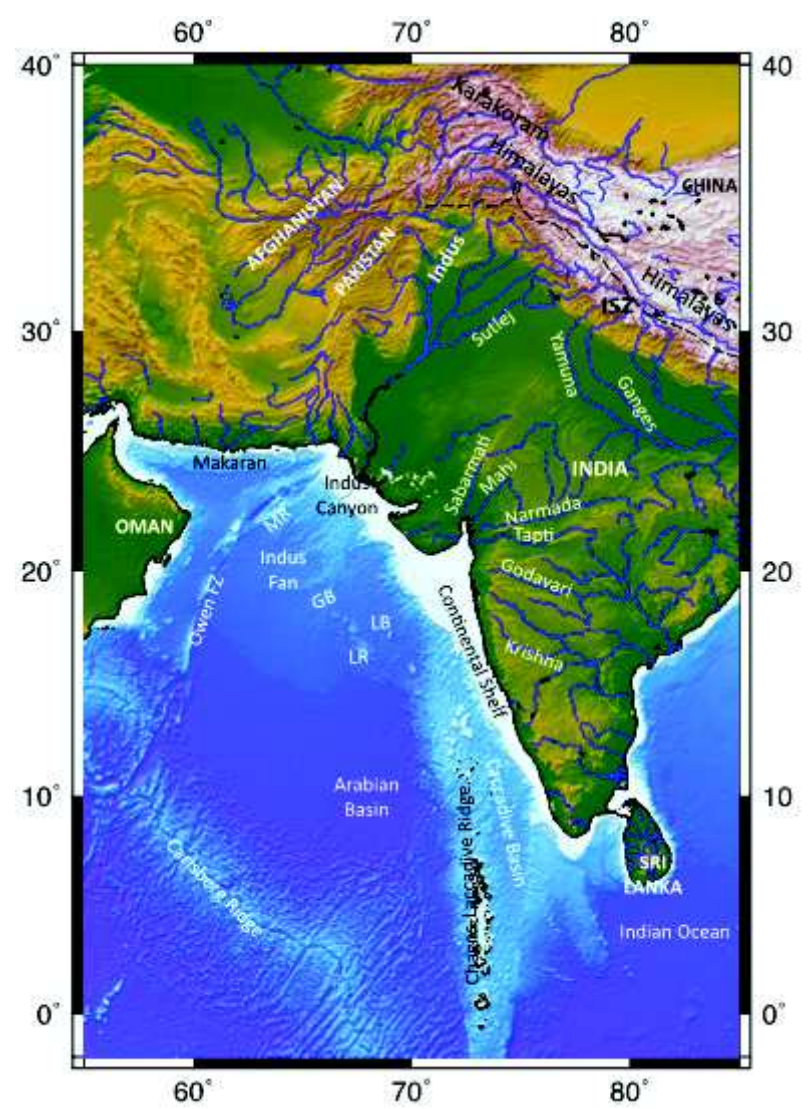

Fig. 1: Major physiographic features along the Indian margin adjoining Arabian Sea in the northern Indian Ocean a large amount of sediment and igneous basement core samples form WCMI. Detailed analyses of these core samples would provide key information about the past tectonic evolution of WCMI, at least during the Cenozoic. Drilling and coring operations during IODP Expedition 355 (Pandey et al., 2015; 2016) recovered sediment from Sites U1456 and U1457 in Laxmi Basin, penetrating 1109.4 and $1108.6 \mathrm{~m}$ below sea floor (mbsf), respectively. This expedition recovered Cenozoic sediments dated upto 13.5-17.7 $\mathrm{Ma}$ (late early to early middle Miocene) at Site U1456. The base of the drilling at Site U1457 spans from $\sim 10.9$ to $\sim 62 \mathrm{Ma}$ (with a long hiatus). At both sites, considerable hiatuses are observed spaning $\sim 8.2-9.2$ and 3.6-5.6 Ma.

Initial results from the sediment core samples suggest that the western Himalaya and Karakoram regions must have been dominantly supplying sediment through the Indus and its tributaries to the eastern Arabian Sea since at least $\sim 17 \mathrm{Ma}$. Analyses of mineral assemblages show close affinities with Greater Himalayan Crystalline Sequence, which may have been exposed to the surface by this time. Sediment deposited through the Indus River primarily include minerals that are associated with the Indus Suture Zone (e.g. glaucophane and hypersthene). The top section at Site U1456 recorded younger Pliocene sandy intervals that could have been deposited in lower fan "sheet lobe" settings. Intervals of basin-plain turbidites separated by hemipelagic muddy sections were apparently deposited during the Miocene. Site U1457 in Laxmi Basin is more distal in facies, reflecting its more marginal setting. No major active lobe appears to have affected Laxmi Basin since the late early Pleistocene ( 1.2-1.5 Ma).

The IODP expedition 355 successfully recovered sediment sections spanning the 8 Ma climatic transition, when the monsoon intensity was proposed to have changed significantly. However, the postcruise research suggested no strong evidence for this transition. For the first time, this expedition discovered one of the largest mass transport deposits (MTD) measuring $\sim 330$ and $\sim 190 \mathrm{~m}$ thick at Sites U1456 and U1457, respectively. These MTD sections include an upper sequence of slump-folded muddy and silty rocks, as well as underlying calcarenites and limestone breccias, together with smaller amounts of volcanic clasts, all of which are likely derived from the western 
Indian continental shelf. Identification of similar facies on the regional seismic lines in Laxmi Basin suggests that these deposits form parts of one of the world's largest mass transport deposits.

For the first time, coring of the igneous basement in the Laxmi Basin was achieved through scientific drilling at Site U1457. Recovery of massive basalt and associated volcaniclastic sediment at this site address the key questions related to rifting and volcanism associated with the genesis of Laxmi Basin. In contrast to the existing knowledge the geochemical analyses of Site U1457 lava indicate that these are low-K, high-Mg subalkaline tholeiitic basalts with distinct nascent subduction initiation inputs instead of a typical enriched or mid-ocean-ridge basalts (Pandey et al., 2019). Heat flow measurements at the two drill sites were calculated to be $\sim 57$ and $\sim 60 \mathrm{~mW} / \mathrm{m}^{2}$. Such heat flow values are compatible (Stein and Stein, 1992) with those observed in the average oceanic crust of 63-84 Ma age, as well as with the presence of highly extended continental crust.

\section{Offshore/onshore Extension of Deccan Volcanism}

The Deccan Flood Basalts (DFB) located in centralwestern India is one of the most remarkable volcanic provinces on Earth covering an almost one-sixth area of the Indian continent. The paleogeographic models generally suggest that the DFB must have covered large areas of the Indian continents and surrounding ocean floor. The peak Deccan volcanism is considered to have occurred in less than one million years during the magnetic Chron 29r ( 65.6-64.8 Ma) around the Cretaceous-Tertiary boundary. The corresponding period is simultaneously linked to the separation of the Seychelles microcontinent from India.

Pande et al. (2017) carried out a geochronological investigation on the tholeiitic flows and dykes in the Ghatkopar-Powai area located in the structurally disturbed Panvel flexure zone. Dating of the seaward dipping pre-flexure flows and the sub-vertical postflexure dykes yielded ${ }^{40} \mathrm{Ar} /{ }^{39} \mathrm{Ar}$ ages of $62.5 \mathrm{Ma}$ indicating that the Panvel flexure may have formed very rapidly and instantaneously at $\sim 62.5 \mathrm{Ma}$. Since the estimated age of $62.5 \mathrm{Ma}$ coincides with the several important events in terms of offshore tectonics adjacent to the northwest coast of India, they attempted to correlate the $62.5 \mathrm{Ma}$ old onshore- offshore magmatism with the India-Laxmi RidgeSeychelles breakup. Considering the geographical extent of various offshore tectonic elements in this region and the interpreted ages for the formation of Raman-Panikkar-Wadia seamounts in the Laxmi Basin, Pande et al. (2017) inferred that the onshore Ghatkopar-Powai tholeiitic flows and dykes and the offshore Raman-Panikkar-Wadia seamount chain were formed contemporaneously, by a single intense phase of Deccan volcanism occurred at $\sim 62.5 \mathrm{Ma}$.

Although it is reasonably established that the voluminous magmatism occurred onshore, its offshore components, are not yet completely estimated. Some consider that nearly an equivalent area of flood basalt, adjoining the DFB on the continent, is submerged offshore. Some of the recent studies have attempted using constraints from regional seismic and industry borehole data. In continuation of this work, Kumar and Chaubey (2019) attempted delineation of the basalt extent on the offshore region using P-wave velocity in flood basalt as a proxy, drilling information and presence of seaward dipping reflectors. The P-wave velocity in the flood basalt varies from 4.1 to $5.2 \mathrm{~km} /$ $\mathrm{s}$. Apart from some isolated basement-high features, they found that flood basalts are underlain by thick sediment and carpets almost the entire WCMI extending up to the Laxmi-Laccadive ridges. The depth of occurrence of flood basalt ranges from $800 \mathrm{~m}$ to $7400 \mathrm{~m}$, with a maximum thickness of $\sim 3900 \mathrm{~m}$ at the foot of continental slope near the eastern part of the Laxmi Basin suggesting that the volcanic emplacement was controlled by existing tectonic features in the region.

\section{The Crustal Affinity of Isolated Offshore Tectonic Blocks}

Extensive Deccan volcanism, followed by the IndiaSeychelles rifting and break up resulted in the genesis of several isolated tectonic fragments offshore WCMI. Some of the prominent ridge-depression couplets include Laxmi Ridge/Laxmi Basin, Kori Comorin Ridge (KCR)/Kori Comorin Basin (KCB), Laccadive Ridges/Basins, besides several marginal basement arches. Information about their precise crustal affinity has remained elusive for a long time due to paucity of adequate geophysical/geological data. For example-crustal nature of the much-debated Laxmi Basin, conducted between the Laxmi Ridge 
and continental shelf (Fig. 1), holds key to unravel late-stage Gondwana break up and magmatism during genesis and evolution of the WCMI. This uncertainty has led to the proposition of a plausible model detailing the mechanism of continental extension in the Laxmi Basin.

Pandey and Pandey (2015) identified faultbounded syn-to post-rift sediments on the shelf with varying hiatuses in sedimentations as unconformities along this margin. Of the two types of crustal domains proposed, the stretched crust proposedly contains several fault-bounded horst and graben structures. These authors also identified very low angle listric faults in the upper crust near continental shelf decoupling detachment surfaces. The transitional type crust to the west experiences heavily intruded sills and basaltic volcanism, that might have been emplaced due to the melting of the subcontinental mantle (SCM) after hyper-stretching of crust and serpentinization of the SCM. The axial ridge in the Laxmi Basin, Panikkar Ridge, is proposed to be one such basaltic volcanic body derived from melting of the lower part of the SCM.

Another study by Misra et al. (2015) argued that the presence of outer and deeper Seaward Dipping Reflectors (SDRs), axial magma chambers, sediment unfilled rift valleys, etc. indicated that the Laxmi Ridge is most plausibly a fossilized spreading center. High resolution, deep $(\sim 25 \mathrm{~km})$ seismic data revealed that (i) the ridge possesses $>15 \mathrm{~km}$ deep sea-ward dipping reflector (SDR) packages; (ii) normal faulted rift valleys devoid of syn-rift sedimentary packages; and (iii) axial magma chambers $5-7 \mathrm{~km}$ beneath the ridge top, deducing that the ridge most possibly comprises of high density (oceanic) crust and a fossil spreading center. Numerical models suggested that the medium spreading rates and high magmatic heating due to the Reunion plume and young plates favored rapid and repeated ridge jumps towards the plume.

\section{Pseudofaults, Tectonic Subsidence and Post-Rift Sedimentation on the WCMI}

The most enigmatic tectonic element in the northeastern Arabian Sea, Laxmi Ridge (LR), a prominent basement high feature with negative gravity anomaly, is buried under $0.5 \mathrm{~km}$ thick sediments and an average water depth of about $2.8 \mathrm{~km}$. It is about $100 \mathrm{~km}$ in width and runs over a length of approximately 700 $\mathrm{km}$ consisting of isolated submarine structural highs extending NW-SE between latitudes $14^{\circ}-19^{\circ} \mathrm{N}$ and longitudes $64^{\circ}-69^{\circ} \mathrm{E}$. The crustal modelling by Nair et al. (2015) with wavelength filtering and spectral analysis of geopotential data suggested that the Laxmi Ridge is divided into two distinct segments with a thick lower crust overlying Moho in the EW segment while the Moho is overlain by a thick underplated material in the NW-SE segment. It is also inferred that the division of Laxmi Ridge into an EW and NW-SE segments with varied evolutionary history is possibly controlled by the Girnar fracture zone. The southwest extension of the Girnar fracture zone appears to mark the boundary between the E-W and NW-SE segments of the Ridge, which depict structurally and characteristically different nature.

Sreejith et al. (2016) mapped the spatial extension of pseudofaults in the Arabian Basin. They explored the role of pseudofaults in the genesis of proximal seamounts and transferred crust during the Paleocene spreading ridge propagation. The anomalous basement undulations in the transferred crust suggests extensive shearing and rotation of preexisting oceanic crust between propagating and dying ridge segment. Similarly, in the conjugate Eastern Somali Basin, seamounts are aligned along NE-SW direction forming $\sim 300 \mathrm{~km}$ long, characterized by gravity high of about $150 \mathrm{mGal}$ with a prominent flanking low. Admittance analysis and Flexural model studies indicated that the seamount chain is isostatically compensated locally with Effective Elastic Thickness (Te) of 3-4 km. which implied that the seamounts in the Arabian Basin were formed by spreading ridge propagation and they found to be associated with pseudofaults, whereas the seamount chain in the Eastern Somali Basin might have probably originated due to melting and upwelling of upper mantle heterogeneities in advance of migrating/ propagating paleo Carlsberg Ridge.

The Paleocene-recent post-rift subsidence history reported by Pandey et al. (2017) in the Mumbai Offshore Basin (MOB) off WCMI revealed considerable thermo-tectonic subsidence over last ca. 56 Myr. Reverse post-rift subsidence modeling with variable $\beta$ stretching factor predicts residual topography of ca. $2000 \mathrm{~m}$ to the west of Shelf Margin Basin and fails to restore late Paleocene horizon and 
the underlying igneous basement to the sea level. This potentially implies that: (1) the igneous basement formed under open marine environs during the late Cretaceous period; and (2) a laterally varying postrift cumulative subsidence occurred within MOB during ca. 68 to ca. 56 Ma. Pre-depositional topographic variations at ca. $56 \mathrm{Ma}$ across the basin could be attributed to the extensional processes such as varied lower crustal underplating along WCMI. Investigations about basement tectonics after unroofing of sediments since late Paleocene from this region support a transitional and heavily stretched nature of crust with high to very high $\beta$ factors. Backstripping and decompaction derived sediment accumulation rates showed that maximum sedimentation occurred during late Miocene. Such an increase in sedimentation rate is in conformity with previous studies (Pandey et al., 2018 and references therein) linking late Miocene Himalayan-Tibetan uplift and subsequent intensification of Indian monsoon system.

Pandey et al. (2018), through a similar analysis extending further west in the Laxmi Basin, used 2D reverse post-rift modelling to suggest that the Laxmi Basin has undergone an extreme stretching of then existing crust since Late Cretaceous time similar to a transitional/oceanic type crust. The flexural backstripping of post-rift sediments from interpreted seismic profiles supported the presence of a hyperthinned crust underneath the Laxmi Basin, with $\beta$ factors reaching $>7$ in the basin center and $>3$ across much of the basin width. The sediment accumulation rates show that maximum sedimentation occurred during Plio-Pleistocene time with a major increase after $10.8 \mathrm{Ma}$. Computations of decompacted sediment accumulation rates in light of new results from International Ocean Discovery Program (IODP) Expedition 355 show that basin sedimentation peaked during the early-middle Miocene time, possibly coeval with uplift and erosion of the Himalayan-Tibetan Plateau driven by strong summer monsoon rains.

Mishra et al. (2018) carried out analyses of coherence and admittance between Mantle Bouguer Anomaly (MBA) and sediment corrected bathymetry, Geoid to Topography Ratio (GTR) forward gravity models and magnetic anomaly provided new understanding on elastic plate thickness, isostatic compensation, subsurface loading and crustal nature of the Laxmi Ridge. The effective elastic plate thickness calculated over the Laxmi Ridge is proposedly between 3 to $4 \mathrm{~km}$ with subsurface to surface load ratio of 0.8 . This low value of Te implies that the Laxmi Ridge is compensated locally (Airy Type) and the lithosphere is elastically weak beneath the ridge. High amplitude ( $>400 \mathrm{nT})$ magnetic anomaly over the southern part of the ridge reveals several lineations in WNW-ESE direction suggesting magma outpouring along weak zones. Geoid to topographic ratio over the ridge is negative $(-1.98 \mathrm{~m} / \mathrm{km})$, possibly indicating shallow subsurface load $(<20 \mathrm{~km})$ with small wavelength $(<200 \mathrm{~km})$. Considering the negative gravity anomaly, low Te and negative GTR over the Laxmi Ridge, could be caused by various rifting processes (stretching, crustal necking, crustal thinning, fracturing, volcanic loading, etc.) between India, Madagascar, Seychelles and Laxmi Ridge during midCretaceous to early Tertiary and reheating of the lithosphere by Réunion hotspot from $67 \mathrm{Ma}$ to $60 \mathrm{Ma}$ suggesting that the ridge could be an extinct spreading ridge.

Rao et al. (2018) revisited available onshore and offshore seismological and residual geoid anomaly constraints from the NW Indian margin. Their inference about the crustal structure and lithosphereasthenosphere boundary (LAB) provided valuable insights into along Indian margin especially with reference to the Deccan volcanic province (DVP). Their study revealed significant variations in upper mantle characteristics between the NW and southcentral parts of DVP having thinner lithosphere in the NW part. The depth to LAB ranges $80-130 \mathrm{~km}$ at the margin with gradual thinning towards the western offshore having a sharp gradient in the south and gentle gradient in the north. The effective elastic thickness (Te) computed through 3-D flexural modeling indicated that the Te values are in general lower in the region and range $12-25 \mathrm{~km}$. Such lower Te values could be ascribed to the combined effect of the lithosphere stretching during Gondwana fragmentation in the Mesozoic and subsequent thermal influence of the Reunion plume. Based on the crustal stretching factors $(\beta)$, Te estimates and the modeled lithosphere geometry at the margin it is proposed that the lithosphere below Laxmi-Gop basin region $(\beta>3.0)$ had undergone continuous stretching since IndiaMadagascar rifting ( $\sim 88 \mathrm{Ma}$ ). Due to syn-rift cooling, the developed necking zone (brittle-ductile 
deformation) got ceased and led to the development of a new necking zone between Seychelles and Laxmi Ridge. Subsequent stretching between Seychelles and the Laxmi Ridge contemporaneous with the Deccan flood basalts eruption led to the seafloor spreading in the Western Basin.

\section{Role of Major Structural Elements in the Regional Tectonics along the Southwestern (SW) Continental Margin of India}

The southwestern continental margin of India encompasses an arcuate Chagos-Laccadive Ridge, triangular-shaped Laccadive Basin, highly intruded shelf margin basin and a thin continental shelf. The shelf edge along the WCMI is continuous and not disturbed in the northern part whereas to the south (south of $16^{\circ} \mathrm{N}$ ) it appears affected by the onshore tectonics. The basement structure revealed faulted blocks with horst/graben pattern along the SW margin of India. The marginal highs are sediment deprived whereas thick sediments are observed in surrounding areas with thickness ranging up to 2-3s (TWT). The sedimentary sequences surrounding margin highs are often terminated sharply giving rise to steep faulting against the footwalls. A thin layer of sediments overlies the Laccadive Ridge and the basement appears heavily faulted depicting obvious high abnormal gravity anomaly. The basement in Laccadive Basin is highly faulted and low in gravity.

A detailed morphometric analysis by Bijesh et al. (2018) along the southwestern continental margin of India identified a total 33 individual bathymetric high features classified as seamounts, hills, knolls, guyots, and plateaus based on the standardization of undersea features. These features are associated with characteristic gravity highs superimposed over regional negative anomalies and complex negative and positive magnetic anomalies. Some of these identified features are extrusive in nature, while others are intrusive. The genesis of the bathymetric highs mapped in the southwestern continental margin of India closer to the Alleppey-Trivandrum Terrace Complex attributed to Marion hotspot volcanism while those in the Laccadive Basin and eastern sector of the Laccadive Plateau related to Réunion hotspot volcanism.

Unnikrishnan et al. (2018) brought out detailed crustal structure and sedimentation history over the
Alleppey platform using marine seismic and gravity data. The KK basin is situated south of the ENEWSW trending Vengurla Arch, sub-divided by the Tellicherry basement arch into the Konkan Basin in the north and the Kerala Basin in the south. Prominent structural/morphological features in this basin include the Alleppey platform and the Vishnu Fracture Zone (VFZ). The Alleppey Platform is a typical marginal plateau developed in the southern-most part of the basin south of Cochin. Seismic interpretation along this region revealed that the Alleppey Platform is associated with a basement high in the west of its present-day geometry, and the platform subsequently started developing during the Eocene period and attained the present geometry by the Miocene. Both the Alleppey platform and the Vishnu fracture zone have had a significant impact on the sedimentation patterns. The Vishnu Fracture Zone appears as a crustal-scale feature at the western boundary of the Alleppey platform. The residual gravity anomalies and gravity models indicate that the VFZ is a crustal-scale feature. The constrained crustal models reveal a depressed Moho geometry below the basement high with Moho at a maximum depth of about $28 \mathrm{~km}$ and this trend extending southward in the deepwaters parallel to the shelf edge. A minor rise in Moho by 3$4 \mathrm{~km}$ is observed east of the Alleppey platform which deepens eastward below the Indian shield. This led to propose that the basement high associated with the Alleppey platform could be a continental fragment associated with the stretching and faulting at the margin.

Earlier plate tectonic reconstructions implied that the VFZ on the Indian side and the Mauritius Fracture Zone on the Madagascar side are aligned at chron C22ny ( $49.04 \mathrm{Ma})$. Based on the near collinearity of gravity anomaly trends, Suhail et al. (2018) opined that the Chain-Kairali Escarpment appears to be the landward extension of the Vishnu FZ. At chron C34ny ( 83.0 Ma), the Chain-Kairali Escarpment appears to be in close proximity to the incipient Mahanoro Fracture Zone. A revised plate reconstruction model by them suggested that the Chain-Kairali Escarpment may have been formed due to the strike-slip motion between the southeast coast of Madagascar and the then southwest coast of India during the initial stages of India-Madagascar breakup. The migration of the Chain-Kairali Escarpment from the proximity of the Mahanoro FZ and aligning with the Vishnu FZ was 
the result of several successive events. An episode of asymmetric crustal accretion due to ridge propagation between India and Madagascar since initiation of spreading around chron C34ny ( 83.0 Ma) to a time between chrons C33no $(\sim 79.08 \mathrm{Ma})$ and C33ny ( 73.62 Ma). This was followed by a major re-organization of the spreading center around C33ny ( $\sim 73.62 \mathrm{Ma})$ when the direction of spreading in the Mascarene Basin changed from $\sim \mathrm{E}-\mathrm{W}$ to $\sim \mathrm{NE}-\mathrm{SW}$ direction. The Chain-Kairali Escarpment and associated crustal weak zones offshore India appear to have facilitated subsequent initiation of the Mauritius FZ and its conjugate Vishnu FZ during a plate reorganization at about chron C33ny. The cessation of spreading in the Mascarene Basin and development of full extent of the Carlsberg Ridge, shortly after chron C27ny (60.92 Ma), resulted in the initiation of a long transform fault, coinciding with the VFZ, which connected the Carlsberg Ridge with the spreading center of the Madagascar Basin. Plate reconstructions suggested that the Chain-Kairali Escarpment is an older, India-Madagascar breakup related feature, formed when the southwest coast of India started moving past southeast coast of Madagascar at around 88.0 Ma. The Vishnu FZ is a much younger feature, initiated at around chron C33ny (73.62 Ma). The Chain-Kairali Escarpment was closer to the transform fault, which later developed into the Mahanoro FZ. However, episodes of spreading cente re-organization brought it to the present position, where it appears as nearly collinear with the Vishnu FZ. In view of these, we conclude that the Chain-Kairali Escarpment is not a landward extension of the Vishnu FZ. These features were formed at different time, and during their evolution, they became part of a system of a long offset transform fault, which gave rise to their collinear existence.

Kunnummal et al. (2018) estimated crustal thickness and Moho depth variations over Maldive Ridge and adjoining areas through the inversion of Complete Bouguer Gravity Anomalies (CBA) and Mantle Residual Gravity Anomalies (MRGA) along the Greater Maldive Ridge. Their analyses did not show much variations in the computed Moho depth with and without the thermal and pressure gravity corrections suggesting that the crustal thickness of the ridge does not depend on the oceanic isochrones used for thermal corrections. Over the Greater Maldive Ridge, a thicker crust and deeper Moho (7 $\mathrm{km}$ to $28 \mathrm{~km}$ ) is obtained, with both the crustal thickness and Moho depths decreasing from north to south. The thick crust over the Maldive Ridge (average $22 \mathrm{~km}$ ) is explained as either due to magmatic underplating from the Reunion plume or a continental crust.

Further Kunnummal and Anand (2019) performed appraisal of Indian Ocean Geoidal Low (IOGL) corrected free-air gravity data over the Maldive Ridge, Deep Sea Channel between Maldive Ridge and Chagos Bank and parts of the adjoining Arabian Basin and Central Indian Basin to infer that the VFZ extends north of the equator and also extend into the previously assumed ocean-continent boundary. While the gravity anomalies associated with the shallow to intermediate wavelength anomalies over the MR reflected the reef platforms/top of the lava flow unit/acoustic basement, the long wavelength anomalies reflected the signature of the underplated material related to the movement of Indian plate over the Reunion hotspot.The depths obtained from spectral analysis compared to that computed from twodimensional forward modeling inferred that the shallow depth corresponds to the top of the acoustic basement underlying 1-1.5 km thick lava flow unit while the deeper associated with the interface between the crust and initial Moho before the underplating took place.

Sreejith et al. (2019) carried out 3-D flexural modeling and coherence analysis of satellite-derived gravity over the Chagos-Laccadive Ridge (CLR). They reported that the northernmost part of CLR is associated with low Te of $3 \mathrm{~km}$ with high subsurface to surface loading ratio. However, further south, the Maldive Ridge and Chagos Bank have fairly uniform Te of 8-10 km with very low loading ratios. They hypothesized that the Laccadive Ridge could be a continental sliver possessing underplated magmatic rocks caused by the Reunion hotspot volcanism. The Maldive Ridge and Chagos Bank appear to have emplaced on a lithosphere of intermediate strength possibly on the flanks of Central Indian Ridge.

\section{Plate Kinematic Reconstructions of the Western Margin of India}

Recent plate kinematic reconstruction models from the Indian Ocean suggest that the deep ocean basins adjoining WCMI have evolved largely due to break- 
up and dispersal of India, Seychelles and Madagascar continental blocks since Late Cretaceous. Ramana et al. (2015) reinterpreted marine magnetic data in the Gop and Laxmi Basins to suggest that the underlying oceanic crust was accreted contemporaneously from $79 \mathrm{Ma}$ at slow half spreading rates $(0.6$ to $1.5 \mathrm{~cm} / \mathrm{yr})$ separating the SeychellesLaxmi Ridge complex from India. The spreading ridge became extinct at $\sim 71 \mathrm{Ma}$ in the central region between $19-20^{\circ} \mathrm{N}$ and $65.5-67^{\circ} \mathrm{E}$, and at $68.7 \mathrm{Ma}$ in the Gop Basin (GB). Extinction progressed southwards with time until $64.1 \mathrm{Ma}$ at $\sim 14.5^{\circ} \mathrm{N}$ in the Laxmi Basin. This spreading probably limited the seafloor spreading in the northern Mascarene Basin, while normal to fast-spreading continued in the south. A fracture zone perhaps acted as a major boundary between the northern and southern Mascarene Basin restricting the southward propagation of the Laxmi Basin spreading ridge.Their plate reconstruction model suggested the formation of Seychelles-Laxmi Ridge microplate by $79 \mathrm{Ma}$ in a complex three-plate system. This microplate might have existed up to $64.1 \mathrm{Ma}$ and experienced an anticlockwise rotation of about $50^{\circ}$. Under the influence of Deccan hotspot activity, the Laxmi Basin spreading ridge jumped southwestward splitting the Seychelles-Laxmi Ridge complex and initiating the Carlsberg Ridge. The presence of about $160 \mathrm{~km}$ of oceanic crust in the Gop and Laxmi Basins partially reducing the space problem faced in the earlier plate reconstruction models.

Bhattacharya and Yatheesh (2015) put forward another plausible model for the early evolution of this region. Their modeling considers that at around 88.0 Ma associated continental blocks in the region were in their immediate pre-drift configuration where a wide continental rift zone existed between India and Madagascar. Seafloor spreading in the Mascarene Basin commenced shortly before 83.0 Ma. A ternary rift system off Saurashtra peninsula of western India, formed shortly before $68.5 \mathrm{Ma}$, reached seafloor spreading stage in the Laxmi and Gop Basins around 67.6 Ma and 64.7 Ma respectively. Around $62.5 \mathrm{Ma}$ the ancestor of the Carlsberg Ridge spreading center developed between the Seychelles Plateau and the Laxmi Ridge while spreading in the northern Mascarene Basin ceased and spreading in the Laxmi and Gop Basins continued at very slow rate. Between 60.9 Ma and 57.9 Ma the spreading in the southern Mascarene Basin also ceased and the spreading center jumped north between the Laccadive Plateau and the northern boundary of the Mascarene Basin. The divergence regimes of the Gop, Laxmi and Laccadive Basins ceased between 57.6 Ma and 56.4 $\mathrm{Ma}$, and the Laccadive Plateau and the Laxmi Ridge got welded to the Indian plate.

Ratheesh-Kumar et al. (2015) presented another plate reconstruction based on elastic thickness (Te) and Moho depth data around Indian margins. They proposed that a linear zone of anomalously low-Te (1-5 km) along the WCMI $(\sim 1680 \mathrm{~km})$, which correlates well with the low-Te patterns obtained all along the eastern continental margin (ECM). The lowTe zone along the western margin of India is attributed to the presence of a failed rift and of the volcanism in the stretched continental lithosphere, which is manifested by coincident linear structural features along the shelf basement. The correlation of these mirrored low-Te zones enabled the best possible fit of India against Madagascar. These low-Te zones along the WCMI and ECM represented paleo-rift inception points of lithosphere thermally and mechanically weakened by the combined effects of the Marion hotspot and lithospheric extension due to rifting.

\section{Channel Morphology, Erosional Sedimentation and Seismic Stratigraphic Framework in the Arabian Sea}

Indus fan, world's second-largest modern submarine fan, hosts a well-developed active canyon and deepsea channel system. The presence of active channel systems has been well reported in the upper Indus Fan. Whereas a detailed bathymetric analysis by Mishra et al. (2015) in the middle Indus Fan revealed that highly sinuous deep-sea channel systems also extend further south to the east as well as to the west of Laxmi Ridge, in the northern Arabian Sea. An average total length of all channels along the channel axis is about $915 \mathrm{~km}$ with a varying spread of 189.8 to $1980.5 \mathrm{~m}$ having an average depth about $60 \mathrm{~m}$. The longest channel is about $256.3 \mathrm{~km}$ long, $702 \mathrm{~m}$ wide and about $57 \mathrm{~m}$ deep. The channels identified are highly sinuous in nature, their meanders and cutoff meanders are similar to the characteristics of fluvial channels. The change in sinuosity reflects the trajectory of the channels. Presence of any subsurface elevations determined the course/pathway of active 
sediment transport systems, as well as their source characterization. The geometry suggested a series of punctuated avulsion events leading to the present array of disconnected channels by tracing back through the middle and upper Indus Fan channel systems using flow accumulation and flow direction modeling. Such channels have affected the Laxmi Basin, in the North, since the Pliocene and are responsible for reworking older fan sediments, resulting in loss of the original erosional signature supplied from the river mouth. This implies that distal fan sediments have experienced significant signal shredding and may not represent the erosion and weathering conditions within the onshore basin at the time of sedimentation. As a follow up to these studies, Ramesh et al. (2015) used GIS techniques on the data from Arabian Sea to develop an algorithm for estimating projected channel paths. This technique could be useful in assessing prospective flow directions under known morphological scenario.

To the south, off Goa, along the inner continental shelf of the west coast of India, mapping of sediment sequences by Dubey et al. (2019) from single-channel high-resolution shallow seismic data revealed a multicycle channel incision beneath 4-15 m thick sediments. The three identified prominent subaerial unconformities indicated three phases of incision varying from a straight channel type to ingrown meander and then to anastomosing channel types. The width of the preserved main channel varies from $\sim 100$ $\mathrm{m}$ to $1000 \mathrm{~m}$ with a maximum channel depth up to $\sim 35 \mathrm{~m}$ by the time it reaches the confluence point. A qualitative and quantitative study of the geomorphologic feature along this channel suggested that the Phase- 2 incisions ( 320-125 kyr BP) had more sediment discharge compared to Phase-3 incisions ( 115-10 kyr BP) implying that the Indian summer monsoon was better during formative stages of Phase2 incisions. Within the shallower water depths, 2 zones of gas trapped sediment charges were identified whose signatures revealed the controlling factors of sediment deposition and its source. Zone 1 is appeared to be confined within the Maximum Flooding Surface layers (Holocene-MFS, $\sim 30 \mathrm{~m}$ water depth) limited to the southern part of off Goa coast whereas Zone 2 (below Holocene-MFS) comprises of several isolated gas-charged patches distributed throughout at a depth between $\sim 20 \mathrm{~m}$ and $\sim 45 \mathrm{~m}$ water depth. Analysis of sediment core data revealed the gas-charged sediment deposits within Zone-1 formed due to degradation of organic material which is predominantly early Holocene mangrove derived controlled by coastline configuration, long term long-shore current pattern, Holocene rapid sea-level rise and lithological character of the exposed intertidal zone. And Zone 2, formed due to degradation of organic material which was deposited by ancestral rivers during the Post-glacial sea-level rise of the Late Pleistocene. Distribution of Zone-2 appears to be controlled by paleo-rivers of different glacial periods and their hydraulic energy condition during the base level rise.

Desai and Biswas (2018) documented post-rift deltaic sedimentation in the western Kachchh Basin and observed that the northernmost Pericratonic Kachchh Rift Basin is characterized by thick postrift sequence of diachronous mega delta system. The deposition of the deltaic sequence was started from mid-Kimmeridgian to Albian. Delineation of these sediment sequences from older mid Kimmeridgian to Tithonian, "Jhuran Delta" using the ichnological and sedimentological parameters revealed two transgressive events demarcating three subcycles within the megadelta system. The three distinct stages of deltaic evolution are delineated along with the fourth stage of transgression and delta destruction. Stage I is characterized by moderate ichnodiversity represented by nine recurring ichnotaxa, suggesting alternating brackish and fully saline water conditions, which indicate river-dominated deltaic sedimentation. Stage II shows a marked increase in the influence of river (freshwater) water, as indicated by a submarine mass failure that includes debris flow, chaotic and contorted structures, sediment gravity-failure and water-escape structures and suggesting a higher rate of sedimentation. Ichnologically, this phase indicates low ichnodiversity with sporadic occurrences of Ophiomorpha and Palaeophycus. Stage III indicates the mixed dominance of river and wave processes. Sediments deposited in the delta front environment show moderate ichnodiversity with nine ichnotaxa. The Jhuran Delta stage ended with a marine transgressive event and reworking of the deltaic sands, which were overlain by a thick shoreface deposit. Thus, the Upper Jurassic Jhuran Delta represents a river-dominated, wave-influenced delta.

Nair and Pandey (2018) utilized regional seismic data from the Arabian Sea to document Cenozoic 
sedimentation history along the Mumbai Offshore Basin (MOB). Their analyses showed that the central part of WCMI contained seven major sedimentary sequences $(\sim 3.0 \mathrm{~s}$ TWT, thick) and the associated complex fault patterns. Fault related structures were prominent in Shelf Platform whereas the basement in Abyssal Basin appeared highly faulted with interspaced intrusive bodies. The sequences lying above the basement of Late Paleocene to Middle Miocene are also in sync with the direction of extensional faults in the deep basin. Whereas the sediment sequences of Late Miocene and younger depict series of thrusts faults due to higher sedimentation. This led to the development of slumping of sediments, subsidence, marginal basins, rollover anticlines, mud diapirs etc. in the shallower sequences suggesting that the crustal thinning and rifting had deformed the basement of WCMI which holds several horsts/grabens to intrusive type structures along with syn-rift sediments giving rise to detachment faults in the upper crust which leads to volcanism during rift

\section{References}

Bhattacharya G and Yatheesh V (2015) Plate-Tectonic Evolution of the Deep Ocean Basins Adjoining the Western Continental Margin of India-A Proposed Model for the Early Opening Scenario Petroleum Geosciences: Indian Contexts Springer, 1-61

Bijesh C M, Kurian P J, Yatheesh V, Tyagi A and Twinkle D (2018) Geomorphology Morphotectonic characteristics, distribution and probable genesis of bathymetric highs off southwest coast of India Geomorphology 315 33-44

Desai B G and Biswas S K (2018) Postrift deltaic sedimentation in western Kachchh Basin: Insights from ichnology and sedimentology Palaeo Palaeo Palaeo 504 104-124

Dubey K M, Chaubey A K, Mahale V P and Karisiddaiah S M (2019) Buried channels provide keys to infer Quaternary stratigraphic and paleo-environmental changes: a case study from the west coast of India Geoscience Frontiers 101577 1595

Kumar P and Chaubey A K (2019) Extension of flood basalt on the northwestern continental margin of India J Earth Sys Sci 128 1-14

Kunnummal P and Anand S P (2019)Qualitative appraisal of high resolution satellite derived free air gravity anomalies over the Maldive Ridge and adjoining ocean basins, western initiation. This might have been formed due to the extreme stretching of continental crust during Late Cretaceous when Seychelles separated from the Indian mainland. Presence of channel levee systems identified within the sedimentary sequences depicts their role in transporting sediments on distal parts of the margin.

\section{Acknowledgements}

We are grateful to the Volume coordinators Prof. Sunil Bajpai, Prof. D M Banerjee, Prof. A K Jain and Prof.Somnath Dasgupta for providing us an opportunity to present this review. We take this opportunity to thank all the contributing scientists and researchers of various articles for sharing their pioneering work with us for this summary. Bibliographic assistance extended by Mr. Rajeev Yadav is sincerely acknowledged. We also thank Director, NCPOR for his continuous encouragements and support. This is NCPOR Contribution no. P-1/ 2019-20.

Indian Ocean J Earth Sys Sci 169 199-209

Kunnummal P, Anand S P, Haritha C and Rao P R (2018) Moho depth variations over the Maldive Ridge and adjoining Arabian and Central Indian Basins, Western Indian Ocean , from three dimensional inversion of gravity anomalies $J$ Earth Sys Sci 156 316-330

Mishra R Pandey D K, Ramesh P and Clift P D (2016) Identification of new deep sea sinuous channels in the eastern Arabian Sea SpringerPlus 5 1-18

Mishra R, Pandey D K, Ramesh P, Kumar A, Gaonkar K K and Pratap A (2015) Active channel systems in the middle Indus fan: Results from high-resolution bathymetry surveys Current Science 108 409-412

Mishra A, Chaubey A K, Sreejith K M and Kumar S (2018) Tectonophysics Crustal underplating and e ffective elastic plate thickness of the Laxmi Ridge, northern Arabian Sea Tectonophysics $\mathbf{7 4 4}$ 82-92

Misra A A and Gourab M (2014) Near N - S paleo extension in the western Deccan region, India/: Does it link strike slip tectonics with India - Seychelles rifting/ ? Int J Earth Sci 103 1645-1680

Misra AA, Sinha N and Mukherjee S (2015) Repeat ridge jumps and microcontinent separation:insights from NE Arabian Sea Mar Pet Geol 59 406-428 
Müller R D, Yatheesh V and Shuhail M (2015) The tectonic stress field evolution of India since the Oligocene Gondwana Res 28 612-624

Nair N, Anand S P, RajaramM and Rao P R (2015) A relook into the crustal architecture of Laxmi Ridge, northeastern Arabian Sea from geopotential data J Earth Sys Sci 124 613-630

Nair N and Pandey D K (2018) Cenozoic sedimentation in the Mumbai Offshore Basin: Implications for tectonic evolution of the western continental margin of India $J$ Earth Sys Sci 152 132-144

Pande K, Yatheesh V and Sheth H (2017) 40Ar/39Ar dating of the Mumbai tholeiites and Panvel flexure: intense $62.5 \mathrm{Ma}$ onshore-offshore Deccan magmatism during India-Laxmi Ridge-Seychelles breakup Geophys J Int 210 1160-1170

Pandey A and Pandey D K (2015) Mechanism of crustal extension in the Laxmi Basin, Arabian Sea Geodesy and Geodynamics 6 409-422

Pandey D K, Clift P D, Kulhanek D K, Andò S, Bendle J A P, Bratenkov S, Griffith E M, Gurumurthy G P, Hahn A, Iwai M, Khim B-K, Kumar A, Kumar A G, Liddy H M, Lu H, Lyle M W, Mishra R, Radhakrishna T, Routledge C M, Saraswat R, Saxena R, Scardia G, Sharma G K, Singh A D, Steinke S, Suzuki K, Tauxe L, Tiwari M, Xu Z and Yu Z (2016) Expedition 355 summary In Pandey D K, Clift P D, Kulhanek D K and the Expedition 355 Scientists Arabian Sea Monsoon Proceedings of the International Ocean Discovery Program 355 College Station, TX (International Ocean Discovery Program) http://dx.doi.org/ 10.14379/iodp.proc.355.101.2016

Pandey D K, Nair N, Pandey A and Sriram G (2017) Basement tectonics and flexural subsidence along western continental margin of India Geoscience Frontiers 8 1009-1024

Pandey D K, Pandey A, Clift PD, Nair N, Ramesh P and Kulhanek D K (2018) Flexural subsidence analysis of the Laxmi Basin, Arabian Sea and its tectonic implications Geological Magazine 1-14

Pandey D K, Pandey A and Whattam S A (2019) Relict subduction initiation along a passive margin in the northwest Indian Ocean Nature Communications 102248 doi: 10.1038/ s41467-019-10227-8

Ramana M V, Desa MA and Ramprasad T (2015) Re-examination of geophysical data off Northwest India: Implications to the Late Cretaceous plate tectonics between India and Africa Marine Geology 365 1-35

Ramesh P, Pandey D K and Mishra R (2015) Approximation of Flow Patterns for Submarine Channel Systems in the Arabian Sea using a GIS Approach Int J of Adv Remote Sensing and GIS 4 1142-1160

Rao G S, Radhakrishna M and Kumar M (2018) Structure, mechanical properties and evolution of the lithosphere below the northwest continental margin of India Int J Earth Sci 107 2191-2207

Ratheesh-Kumar R T, Ishwar-Kumar C, Windley B F, Razakamanana T, Nair R R and Sajeev K (2015) IndiaMadagascar paleo-fit based on flexural isostasy of their rifted margins Gondwana Research 28 581-600

Saikia U, Das R and S S Rai (2017) Possible magmatic underplating beneath the west coast of India and adjoining Dharwar craton: Imprint from Archean crustal evolution to breakup of India and Madagascar Earth and Planet Sci Lett 462 114 https://doi.org/10.1016/j.epsl.2017.01.004

Shuhail M, Yatheesh V, Bhattacharya G C, Müller R D, Raju KA $\mathrm{K}$ and Mahender K (2018) Journal of Asian Earth Sciences Formation and evolution of the Chain-Kairali Escarpment and the Vishnu Fracture Zone in the Western Indian Ocean J Earth Sys Sci 164 307-321

Sreejith K M, Chaubey A K, Mishra A, Kumar S and Rajawat A $S$ (2016) Pseudofaults and associated seamounts in the conjugate Arabian and Eastern Somali basins, NW Indian Ocean - New constraints from high-resolution satellitederived gravity data J Earth Sys Sci 131 1-11

Sreejith K M, Unnikrishnan P and Radhakrishna M (2019) Isostasy and crustal structure of the Chagos-Laccadive Ridge, Western Indian Ocean: Geodynamic implications $J$ Earth Sys Sci 128 1-13

Stein C A and Stein S (1992) A model for the global variation in oceanic depth and heat flow with lithospheric age Nature 359 123-129 http://dx.doi.org/10.1038/359123a0

Unnikrishnan P, Radhakrishna M and Prasad G K (2018) Geoscience Frontiers Crustal structure and sedimentation history over the Alleppey platform, southwest continental margin of India: Constraints from multichannel seismic and gravity data Geoscience Frontiers 9 549-558. 